\title{
PDGFRA Exon 12 Mutation
}

National Cancer Institute

\section{Source}

National Cancer Institute. PDGFRA EXon 12 Mutation. NCI Thesaurus. Code C116397.

A molecular genetic abnormality indicating the presence of a mutation in exon 12 of the PDGFRA gene located within 4q11-q13. 